\title{
School Variation in General Intelligence
}

\section{Warren W. Coxe}

To cite this article: Warren W. Coxe (1921) School Variation in General Intelligence, The Journal of Educational Research, 4:3, 187-194, DOI: 10.1080/00220671.1921.10879195

To link to this article: http://dx.doi.org/10.1080/00220671.1921.10879195

册 Published online: 15 Dec 2014.

Submit your article to this journal 저

Q View related articles $\square$ 


\title{
SCHOOL VARIATION IN GENERAL INTELLIGENCE
}

\author{
WARREN W. COXE \\ Formerly Vocation Bureau, Cincinnati, Ohio
}

A course of study which shall be of universal application throughout a school system has certain obvious advantages, among which are the following: 1) inasmuch as all pupils of the same grade study the same material at the same time, transfers can be effected easily and without loss of time to the pupil; 2) there can be a greater uniformity of textbooks; 3) courses of study can be worked out in greater detail; 4) many supervisory problems are simplified; and 5) the cost of education is somewhat less. All these advantages are on the side of less work for the teacher and less cost for the community.

We should not forget, however, that student bodies differ greatly in general intelligence and therefore in their ability to pursue a given course of study. Were we to judge the efficiency of teaching by the degree of success with which pupils pass standard educational tests, we might be unfair unless we made allowance for such a factor as the general intelligence of the pupils. It is, therefore, very important that a school superintendent should know the composition of the student bodies in the several schools in terms of general intelligence.

This article presents data regarding the general intelligence of 24 sixth grades in 24 elementary schools in Cincinnati. The examination used was the Otis Group Intelligence Scale. It was given near the end of the year, was administered throughout by two people trained in giving such tests, and was scored by the same two people. The conditions of giving and scoring were thus uniform in all the schools. The results ought therefore to be strictly comparable.

The immediate reason for giving the tests was the selection of candidates for a six-year classical high-school. The tentative basis of selection was a minimum intelligence quotient of 110 .

In Table $I$ is presented the distribution of scores for the 24 schools. The wide variation of scores in any one school is at once noticeable. Schools are not alike in this respect, for some manifest much more variation than do others. Reduction of this 


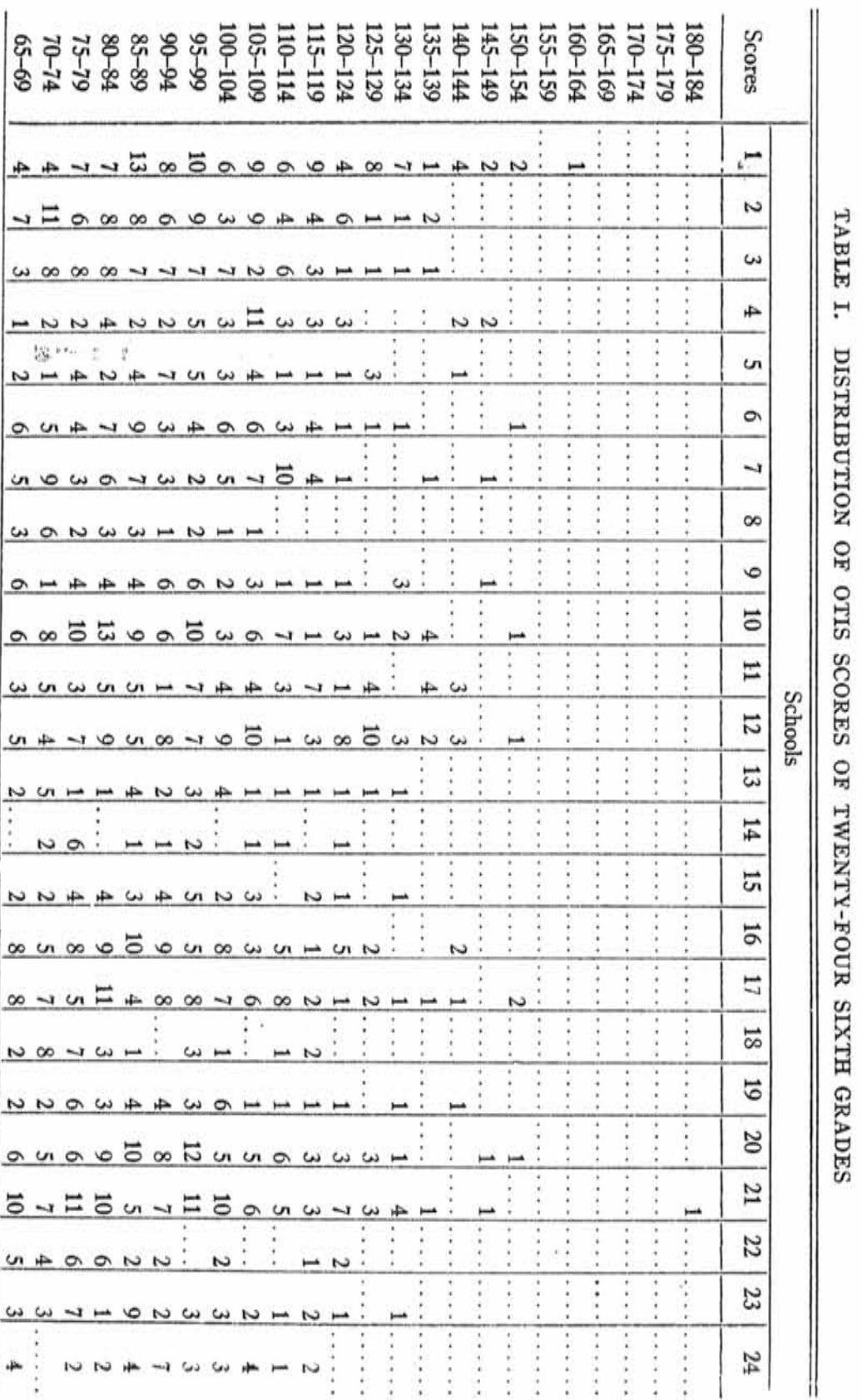




\begin{tabular}{|c|c|c|c|c|}
\hline 䆖窟 & 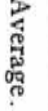 & & 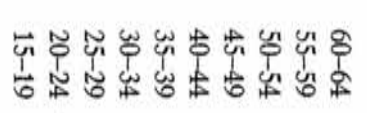 & ర్రి \\
\hline$\vec{\omega}$ & ¿ & $\vec{\sigma}$ & 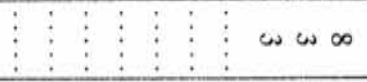 & $\mapsto$ \\
\hline 岕 & $\begin{array}{l}\infty \\
\text { in }\end{array}$ & i & $\vdots \vdots \mapsto \vdots \mapsto \vdots N \mapsto \omega N$ & $N$ \\
\hline 矛 & 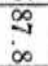 & $\mathscr{8}$ & $\vdots \vdots \mapsto \vdots \vdots \mapsto N \vdots N$ & $\omega$ \\
\hline$\varpi$ & 市 & 空 & $\vdots \vdots \vdots \vdots \vdots \vdots \vdots \vdots \vdots \cdots$ & $\mapsto$ \\
\hline$\vec{\omega}_{\Delta}$ & $\overbrace{i n}^{\circ}$ & 点 & $\vdots \vdots \vdots \vdots \vdots \vdots \vdots \vdots$ wNー & or \\
\hline$\omega$ & $\stackrel{\circ}{\omega}$ & ì & 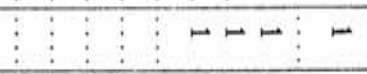 & a \\
\hline 怘 & $\underset{\infty}{\infty}$ & जี & $\vdots \vdots \vdots \vdots \vdots N \mapsto N \omega \mapsto \mapsto$ & $\checkmark$ \\
\hline$\vec{\phi}$ & $\stackrel{9}{\infty}$ & 忍 & 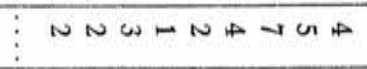 & $\infty$ \\
\hline क् & $\begin{array}{l}8 \\
\omega\end{array}$ & 家 & $\vdots \vdots \vdots \vdots \vdots \vdots \vdots \mapsto \mapsto \mapsto N$ & 0 \\
\hline$\vec{\omega}$ & $\stackrel{\circ}{0}$ & 8 & $\vdots \vdots \vdots \vdots \vdots \vdots \vdots \vdots \vdots$ 元 & $\overrightarrow{0}$ \\
\hline$\vec{\omega}$ & $\begin{array}{l}\infty \\
6 \\
6\end{array}$ & 8 & $\vdots \vdots \vdots \vdots \vdots$ ○ $\vdots \vdots$ & $\Xi$ \\
\hline$\vec{\omega}$ & $\stackrel{5}{8}$ & $\overrightarrow{8}$ & $\vdots \vdots \vdots \vdots \vdots \mapsto \vdots ー ル N$ & $\vec{N}$ \\
\hline $\overrightarrow{v_{N}}$ & $\begin{array}{l}\infty \\
a\end{array}$ & $\bar{U}$ & $\vdots \vdots \vdots \vdots ー ル ー ル N N$ & $\vec{\omega}$ \\
\hline है & के & $\tilde{\omega}$ & $\vdots \vdots \vdots \vdots \vdots$ 一NN $\vdots$ - & 点 \\
\hline 壱 & $\begin{array}{l}\text { பै } \\
\omega\end{array}$ & 专 & $\vdots \sim \vdots \vdots \omega \vdots N a \vdots N$ & $\vec{v}$ \\
\hline$\vec{N}_{0}$ & $\frac{a}{a}$ & ஜ & $\vdots \vdots \vdots N \vdots$ NNW $\vdots$ N & $\vec{a}$ \\
\hline 药 & $\infty_{\infty}^{\infty}$ & $\varnothing$ & $\vdots \vdots-\vdots \vdots \vdots$ cos & $\exists$ \\
\hline 点 & $\begin{array}{l}9 \\
\text { in }\end{array}$ & Un & $w \vdots \omega \mapsto a \mapsto \mapsto-1$ & $\vec{\infty}$ \\
\hline$\vec{心}$ & $\stackrel{\infty}{\omega}$ & G & $\vdots \vdots N$ N $\vdots$ NWW & $\vec{\sigma}$ \\
\hline $\overrightarrow{\omega_{N}}$ & $\stackrel{\circ}{6}$ & I & $\vdots \vdots \vdots \vdots \mapsto \mapsto \mapsto$ & $\tilde{\sigma}$ \\
\hline$\vec{\omega}$ & $\begin{array}{l}\text { is } \\
\text { in }\end{array}$ & 掌 & $\vdots \vdots \vdots \vdots \vdots$ ー心ーゃ & $\sim$ \\
\hline $\overrightarrow{8}_{0}$ & N & \& & 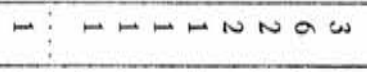 & N \\
\hline $\overrightarrow{n_{0}}$ & $\stackrel{\infty}{\circ}$ & $\stackrel{W}{\oplus}$ & $\vdots \vdots \vdots \vdots-N-\vdots$ a & N \\
\hline$\vec{N}$ & $\prod_{-1}^{\infty}$ & 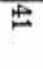 & 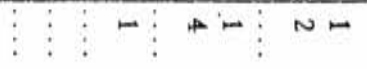 & $\tilde{\perp}$ \\
\hline
\end{tabular}


variation through a reclassification of the pupils should make the work of teaching very much easier and more effective. In another study we found that the variation in mental age was much greater than the variation in chronological age. This means that there is a tendency to allow children to progress in school in accordance with chronological age rather than mental ability, and this partially explains the wide variation of scores just noticed.

But the fact we wish to emphasize especially is the extent to which schools differ in the type of their pupils. This is better shown by a comparison of intelligence quotients. Scores will vary with growth, but the intelligence quotient is presumed to be nearly constant over a considerable number of years. Because of this constancy, the intelligence quotient is used to classify children as dull, normal, bright, or superior.

In Table II is shown the percent of pupils above and below certain intelligence quotients. Compare, for example, Schools 1 and 18. In School 1, 75 percent of the pupils have intelligence quotients of 100 or above; 57 percent of 110 or above; and 25 percent of 130 or above. In School 18 only 22 percent have intelligence quotients of 100 or above; 9 percent of 110 or above; and none of 130 or above. School 12 has children somewhat brighter than School 1; School 8 has duller children than School 18. Between these extremes are all gradations.

An examination of the data of Tables I and II shows that the school averages do not conform to the normal probability curve. This is because the tables do not include as many schools from congested districts as from the better residential sections. Were all schools included, there would be a larger proportion with low averages and the variation would be increased. Furthermore, in none of the schools are the extremely dull included in this grade, for they have failed of promotion and are either to be found in the lower grades or in special schools.

A comparison of these facts with the type of community served by each school is instructive. Following are brief statements descriptive of each community:

School 1-High-class residences; a large proportion of successful business and professional men.

School 2-In a congested district; includes stores and some factories; some foreigners; almost entirely a laboring class.

School 3-Mainly residential, but near factories; laboring class forms a large proportion of the population. 


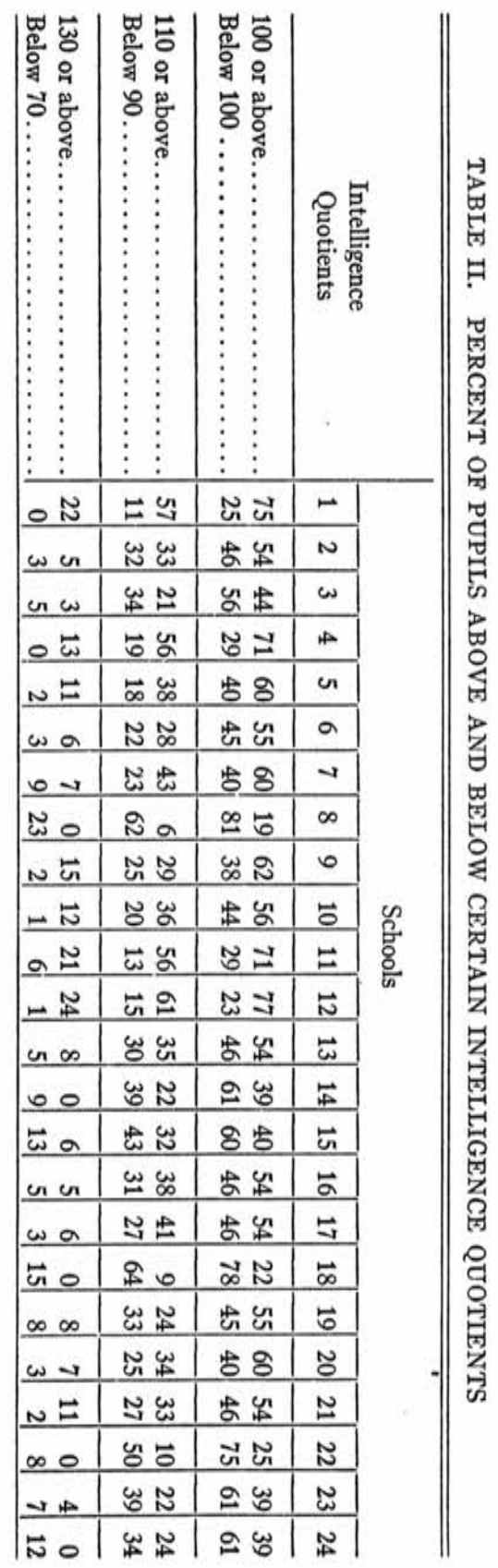


School 4-High-class residences; homes of college professors and professional men; a small part is very wealthy and another part is decidedly tenement. School 5-An outlying district; high-class residences; homes of business and professional men.

School 6-Good residences; homes of business and laboring men; an orphan asylum is within the district and sends its children here.

School 7-Good residences; a great number of excellent apartment houses; homes of business and laboring men.

School 8-Colored children only; a very high-class colored neighborhood; entirely residential; a great many apartment houses.

School 9-Good residences; many home owners; largely business men.

School 10-Thickly settled residential neighborhood; business and laboring men.

School 11-Good residences; apartment houses; business and office men.

School 12-Rapidly growing community; successful business and professional men; high-class residences; very homogeneous.

School 13-Outlying district; almost in an agricultural region; a very stable population.

School 14-Good residential; many negroes; laboring class.

School 15-Semi-residential; near the railroads and river; largely laboring class.

School 16-Part of district is high-class residential, part is tenement; an orphan asylum is in the district.

School 17-Rapidly growing district; mainly residential; homes of factory workers.

School 18-Almost in the heart of the city; very congested; low-class tenements; some foreigners; run-down neighborhood; laboring class.

School 19-Outlying district; has a great many children from an agricultural neighborhood.

School 20-Outlying region; high-class residential; business and professional men.

School 21-Outlying region; very good residences; business and working class.

School 22-Semi-residential; part of district is tenement; foreigners; laboring class.

School 23-Outlying district; fair residential somewhat rural.

School 24-Congested tenement district; run-down neighborhood; partly industrial.

It is manifest that these schools represent widely varying conditions. Children attending School 18 have a very limited home environment and nearly two-thirds of them are classified on the intelligence scale as dull. Children attending such schools as 1 , 4 , or 12 are of a radically different type both as to environment and general intelligence, being much above the average. These varying conditions indicate that the course of study is a problem for each school, to be solved according to local needs. 
Enough experimental work has already been done to suggest how this may be carried out. Whipple and Terman have shown that bright children not only can make rapid progress but can at the same time take an enriched curriculum. It has also been found that dull children can almost never make normal progress through the grades. We thus have three groups, the dull, the normal and the bright, each requiring some special adaptation of the curriculum.

We have shown that these schools varied in the general intelligence of their pupils and that they served communities of very different types. It is also to be noted that there is a correlation between the intelligence level of the pupils and the character of the community. Those with lower intelligence levels generally live in the more congested districts; those with the higher intelligence levels generally live in the outlying, residential sections.

This suggests how the school may adapt itself to its community. Consider, first, how such a school as No. 18 will plan its curriculum. It is evident that it will have to permit its children to progress more slowly than usual, possibly allowing three years to do two grades of work. It should provide some of those things ordinarily found in the home but lacking in most of these homes, such as games, parties, plenty of simple reading, chance to "tinker," etc. Hand work should be provided, partly for cultural reasons, but mainly as a preliminary to vocational training. Since these children can neither make the rapid progress of bright children nor progress as far in school, one would only cause them to fail by urging them to meet the more difficult requirements. Failure tends to breed discouragement and discontent. If, on the other hand, the curriculum is within their capacity and definitely helps them to be self-supporting and to fill a place in society, their self-respect will be maintained and they can become valuable citizens.

Schools having bright children can expect the home to care for much of the training. These children can do more than average work, both in quantity and quality. They can possibly do three grades of work in two years and at the same time have their curriculum enriched. We do not know as yet just how the work should be enriched. A large proportion of such children will enter the professions or fill responsible positions in the business world. These vocations need a very broad foundation and an 
extended amount of training. Anything the school can do to give better preparation in less time will be of great service to the individual as well as to society.

It is not likely that any school will be made up of but one of our three groups. It will generally have all three of them. An analysis of the kind here attempted will show which groups are present and what kind of adjustment is necessary to make the school of most service to its community. 